\title{
The influence of initial tension on blunting of chain saw blades and cutting efficiency
}

\author{
Adam Maciak*, Magda Kubuśka \\ Warsaw University of Life Sciences - SGGW, Faculty of Production Engineering, Department of Agricultural and Forest Machinery, \\ ul. Nowoursynowska 164, 02-787 Warszawa, Poland \\ *Tel. + 4822 5934519, e-mail: adam_maciak@sggw.pl
}

\begin{abstract}
The initial tension of the chainsaw is a decisive factor in making the operator's work more efficient and at the same time it is a parameter that the operator can adjust and thus affect significantly. This article presents the results of research aimed at determining the impact of the initial chain tension on the blunting of the blade and the cutting efficiency. Two tree species, pine and oak, were examined in our research, which enabled us to also compare the effect of the wood hardness on blade blunting. The wood tested in this study was fresh wood. The measurements were carried out with two different degrees of chain tension: tensioned and loose. We found that both, tension and wood hardness, significantly affect the rate of blunting of the saw blades. The dulling occurs more intensively when working with a loose chain and sawing wood with greater hardness. In the case of too small tension on the saw chain, blunting may occur even more than twice as fast compared to working with a properly tensioned saw. The initial tension and tree species also affect the cutting efficiency with too small an initial tension reducing cutting efficiency.
\end{abstract}

Keywords: Petrol chainsaw, saw chain, saw tension, dulling of blades, cutting efficiency

\section{Introduction}

In Poland, timber harvesting is carried out using portable combustion engine chainsaws (petrol chainsaws) or harvesters. In both cases, the saw chains with chipper teeth are used for cutting wood. About $90 \%$ of wood acquired in Poland's forests is harvested using petrol chainsaws and the remaining part - with harvesters (Kusiak et al. 2012, Wójcik 2014). The use of multi-operational machines in timber acquisition increases every year.

Modern technical solutions have improved work safety and ergonomics as well as increased labour efficiency of chainsaw operators (Gendek, Oktabiński 2012). Even with progressive changes in chainsaw design, at some stages of sawing, various events can reduce the efficiency of the wood cutting process. The blunting of chain teeth while cutting wood is one of the most important aspects, directly connected with the cutting process. Even the latest solutions in blade geometry have not been able to eliminate this problem.

Today's chainsaws, even though manufactured by different companies, have similar designs and technical parame- ters. On Poland's market, medium-sized saws produced by Husqvarna and Stihl have the largest share (Murawski 1995; Wójcik 2007; Maciak 2011); chainsaws offered by other companies are purchased less frequently and their contribution to logging in the State Forests is relatively low. Consistent with Więsik (2002), the medium-sized chainsaws are those with cylinder displacement from $40.1 \mathrm{~cm}^{3}$ to $60 \mathrm{~cm}^{3}$.

The widespread use of petrol chainsaws in forestry has encouraged long-term research on the effectiveness of their performance. A detailed analysis of this aspect was carried out by Więsik (1994). This author developed a graph of the relational model of the wood cutting process, enabling the analysis of the influence of basic factors on the efficiency and energy consumption of the wood cutting process. This graph was the basis for the mathematical models built by other authors (Górski 1996; Maciak 2001).

In addition to the parameters, such as chainsaw construction, blade geometry (Maciak 2000; Maciak, Gendek 2007) and the feed force (Maciak 2004), the initial tension of the saw chain has a considerable influence on the cutting efficiency. This parameter depends on the chainsaw operator. Changing the initial

Received: 23.05.2018, reviewed: 13.07.2018, accepted: 24.08.2018. 
tension results in a change of the resistance of the saw chain movement along the guide bar during operation. At the same time, the freedom of swing of the saw chain is changed.

Botwin and Botwin (1979) found that a loose saw chain reduced the cutting efficiency. On the other hand, however, too high a chain tension causes considerable energy loss due to friction and is the cause of earlier wear of the cutting system. Górski (1996) stated that the efficiency of cutting with the loose saw chain is $50 \%$ lower than that achieved in the case when the saw chain is properly tensioned. Trzeciak (2003) confirmed that too high a saw chain tension resulted in the reduced cutting efficiency. To et al. (1971), when analysing the photographs of wood cutting taken with a high-speed camera, observed lessen angular displacement of the cutting blades at the increased initial tension of the saw chain. Maciak (2013) stated that the reduction of the initial tension increased the freedom of swing of the saw chain in the kerf plane. In that case, there is the reduced value of the time index (the ratio of the actual time when the blades are cutting, to the total cutting time), the chainsaw efficiency is worsened, followed by the decrease of the cutting productivity. During chainsaw operation, the chain tension can change dynamically. The reason behind this is the non-uniformity of speed and angular acceleration of the crankshaft, especially noticeable in the case of single-cylinder engines (Gendek 2006). This translates into high values of the chain acceleration, resulting in high inertia forces. The values of inertia forces are often several times higher than the value of active cutting forces (Więsik 2007). In addition to the aforementioned factors, the blade geometry has a large influence on the wood cutting results. Among the geometrical parameters, the angle of inclination of the cutting edge significantly affects the results of cutting (Komorowski 1987; Stempski; Grodecki 1998), the lowering and shape of the feed limiter (Górski 1996) and blunting of the saw blades (Bieńkowski 1993; Górski 1996).

The aim of the present study was to determine the effect of the initial tension of the saw chain on the tempo of blade blunting in the chipper saw chain. During the tests, the influence of the initial tension on the decrease in cutting efficiency was also determined. The tests were carried out on both soft and hard wood.

\section{Material and methods}

The logs (120 cm long) of pine and oak wood were used in the study. The diameter of pine logs ranged from $32 \mathrm{~cm}$ to $40 \mathrm{~cm}$, and that of oak logs - from $32 \mathrm{~cm}$ to $38 \mathrm{~cm}$. The average absolute humidity of pine logs, determined using a moisture analyser WPS 210 S, was $74 \%$, and that of oak wood $-77 \%$. The wood hardness, determined by the Brinell test method on the outward facing surface of the logs, was $14 \mathrm{MPa}$ for pine and $45 \mathrm{MPa}$ for oak. 12 hardness measure- ments were carried out in randomly selected spots on the $\log$ cross-section. The hardness values given above are the average values per the log cross-section.

The tests were carried out for two saw chain tension levels: tensioned and loose. The chain was assumed as tensioned when its deflection was $\mathrm{f}=5 \mathrm{~mm}$ after suspending $20 \mathrm{~N}$ weight in the middle of the guide bar length (Figure 1), and loose when $\mathrm{f}=8 \mathrm{~mm}$. The tension was determined in a similar way in the course of measurements performed by other authors (Bieńkowski 1993; Górski 1996; Gendek 2005).

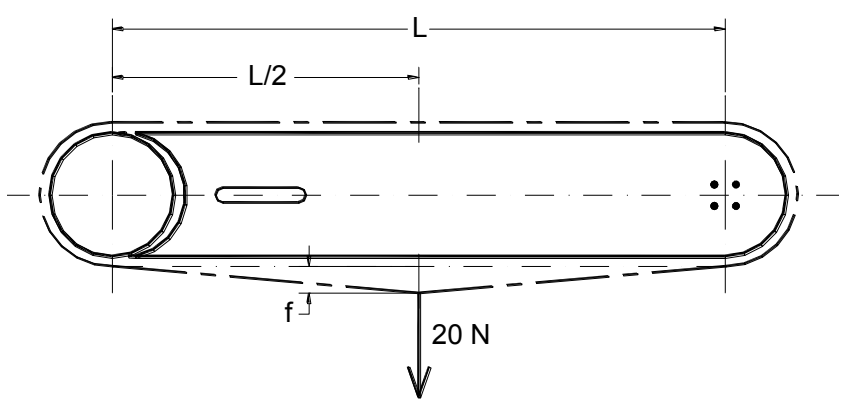

Figure 1. The method of measuring the tension of the chainsaw

The tests were carried out with the petrol chainsaw Husqvarna 257 (cylinder displacement $57 \mathrm{~cm}^{3}$, power 4.1 $\mathrm{kW}$ ). During the measurements, the chainsaw was equipped with a guide bar (Oregon Products, catalogue \# 5089141-56, 15-inch long, $1.5 \mathrm{~mm}$ gauge, sprocket nose).

The saw used for the tests had the following parameters:

- chipper type chainsaw

- tooth pitch: $3 / 8$ "

- angle of inclination of horizontal cutting edges: $65^{\circ}$

- lowering of the feed limiter: $0.5 \mathrm{~mm}$

- number of cutting links: 28 pcs

Two brand new identical saw chains and guide bars were used in the tests. Each saw chain was equipped in own guide bar and was used for the tests on different types of wood. Before test measurements, the saws were placed in an oil bath for 6 hours. Then, with each set "saw chain - guide bar", 50 pine kerfs were made in order to adjust the saw chain and the guide bar, as well as to avoid reducing the chain tension during operation under the factual tests (brand new saw chains tend to extend in the initial period of chainsaw use). Before the factual tests, the saw chains were sharpened. To maintain repeatability of the geometry of the blades, the sharpening was performed with the use of a specific sharpener. The sharpening was repeated after each series of the measurements carried out.

During the measurements, each log was placed on a woodworking bench (60 cm-high) and fixed firmly with a tape in order to prevent reposition during cutting. The same experienced chainsaw operator performed cutting. 
Each measurement series consisted of 35 kerfs. For each test variant (saw chain tension - wood species), measurement series was repeated three times.

During the tests carried out, the following parameters were measured:

- kerf area,

- cutting time,

- radius of the blade rounding.

After the saw chain was sharpened, the impressions of all 28 cutting links (taken at the middle of the length of the horizontal cutting edge) were made using lead plates (Figure 2 a). The blade impressions were also collected after the sharpening at the beginning of each measurement series, and every 5 kerfs during measurements. The blade edge was pressed down several times on each lead plate. This enabled microscopic analyses to select the best-quality blade impression (the most pronounced). The stand for measuring blade blunting consisted in a Nikon ALPHAPHOT-2 microscope equipped with an $\mathrm{OH} 1$ halogen illuminator for observations in reflected light. In order to make the measurement, the plate with the cutting edge imprint was placed on the microscope table. The image from the microscope was transferred to the computer using a digital camera. Using a 400-fold magnification, the image was saved to the computer disk. Next, using the MultiScan Base v.18.03 program, the radius of the blade rounding was measured (Figure $2 \mathrm{~b}, \mathrm{c}$ ).

The kerf area was determined on the basis of two mutually perpendicular diameters, which were measured with a section guide with an accuracy of $1 \mathrm{~cm}$. The mean value of the two measurements was used to calculate the kerf area. The calculations were made using the formula for the area enclosed by a circle. The cutting time was measured using a Casio stopwatch with an accuracy of $0.01 \mathrm{~s}$, starting from the point in time at which the chainsaw contacted the wood to the end of cutting.

The area efficiency of cutting $W\left[\mathrm{~cm}^{2} / \mathrm{s}\right]$ was calculated using the following relationship:

$$
W=\frac{A}{t}
$$

where:

$\mathrm{A}-\operatorname{kerf}$ area $\left[\mathrm{cm}^{2}\right]$,

$\mathrm{t}$ - sawing time [s].

Relationships between the kerf area and the radius of the blade rounding and the cutting efficiency were analysed with the use of linear regression equations and the Pearson's linear correlation coefficients. The significance of differences between the mean values obtained for experimental variants was tested. For this purpose, after checking the normality of data distribution, a test of significance of differences between means was performed with the use of the t-test $(\alpha=0.05)$. Two hypotheses were tested in the statistical inference:
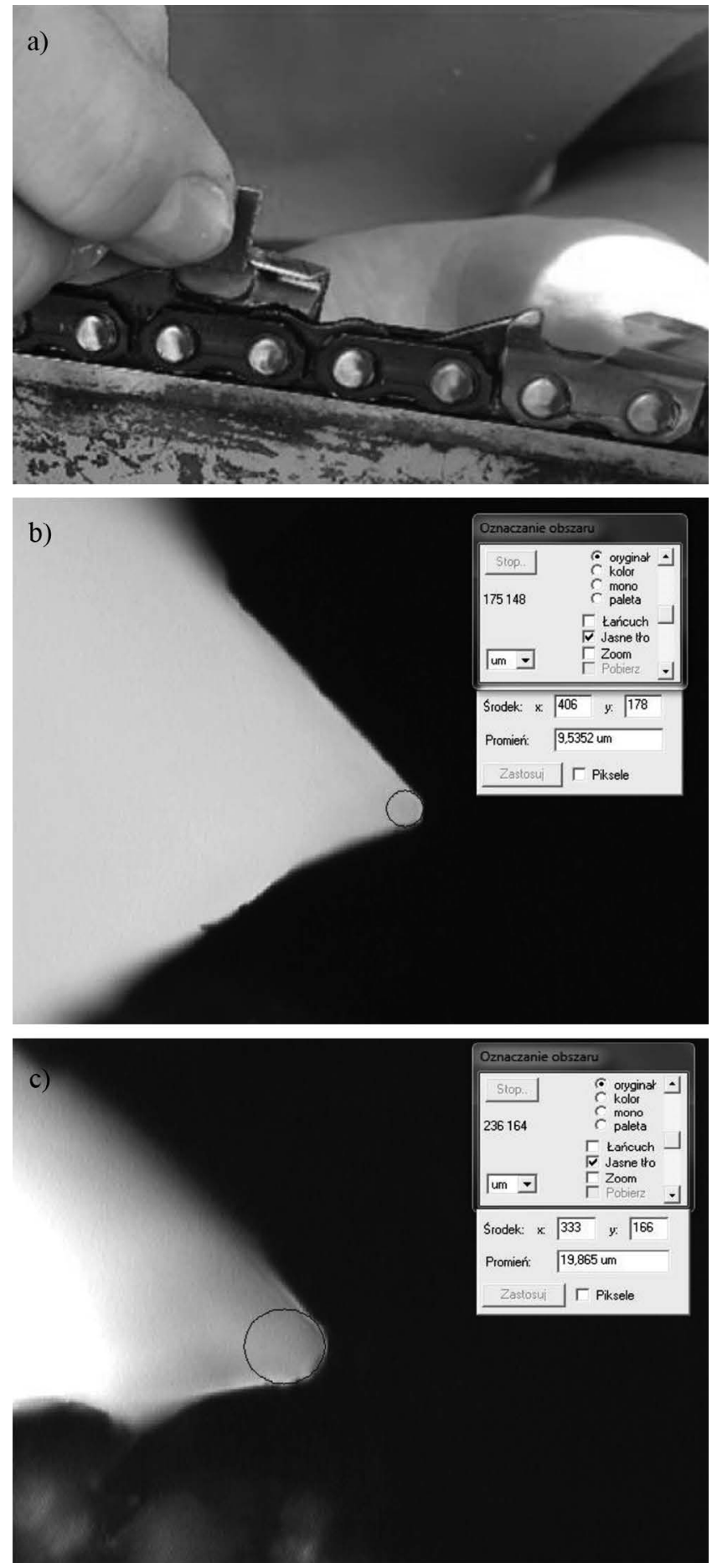

Figure 2. Measuring the radius of the blade rounding: a) The method of downloading the imprint, b) Saw sharp $r=9.53 \mathrm{~mm}$, c) Blunt saw $r=19.86 \mathrm{~mm}$

$\mathrm{H} 0: \mu \mathrm{A}=\mu \mathrm{B}$

$\mathrm{H} 1: \mu \mathrm{A} \neq \mu \mathrm{B}$ 
The null hypothesis was that there was no difference between the means obtained.

If the calculated value of the test probability $(p)$ was less than 0.05 , the null hypothesis was rejected, that is, the differences between the means were assumed to be statistically significant. All statistical analyses were performed by means of Statistica 10 software (StatSoft Inc. 2011).

\section{Results}

Table 1 presents the statistical results obtained for all experiment variants.

In the case of cutting pine wood with the use of the tensioned saw chain, the average radius of rounding of cutting edges increased by $5.98 \mu \mathrm{m}$, from $8.33 \mu \mathrm{m}$ after sharpening to 14.31 $\mu \mathrm{m}$ after 35 kerfs done. The larger increase of the radius was observed in the case of the loose saw chain, from $8.42 \mu \mathrm{m}$ after sharpening to $17.21 \mu \mathrm{m}$ after $35 \mathrm{kerfs}$, that is, the difference was $8.79 \mu \mathrm{m}$. In the case of oak wood cutting with the tensioned saw chain, the increase of the average radius was $9.4 \mu \mathrm{m}$ (from $8.62 \mu \mathrm{m}$ to $18.06 \mu \mathrm{m}$ ). Then, it was larger when compared to pine wood cutting with the use of the saw chain with the same initial tension, even though oak kerf area was smaller by $4922 \mathrm{~cm}^{2}$ (due to a somewhat smaller diameter of oak logs used in the experiment). In the case of cutting oak wood with the loose saw chain, the largest (in the present study) increase in the rounding radius was $12.28 \mu \mathrm{m}$, that is, from $9.06 \mu \mathrm{m}$ after sharpening to $21.34 \mu \mathrm{m}$ after $35 \mathrm{kerfs}$ done.

The obtained values of the standard deviation (SD) after sharpening, ranged from $0.29 \mu \mathrm{m}$ to $0.37 \mu \mathrm{m}$. The diversification of blunting of individual blades increased with the kerf area achieved. The distribution of the values of the radius of the cutting edge rounding depended on the initial tension of the saw chain and the type of wood. In the case

Table 1. Average values of the radius of the cutting edge of the blade obtained in individual cases

\begin{tabular}{|c|c|c|c|c|c|}
\hline $\begin{array}{c}\text { Surface of kerf } \\
{\left[\mathrm{cm}^{2}\right]}\end{array}$ & $\begin{array}{l}\text { The average radius } \\
\text { of rounding of cut- } \\
\text { ting edges } \\
{[\mu \mathrm{m}]}\end{array}$ & $\begin{array}{c}\text { Standard deviation of } \\
\text { radius of rounding of } \\
\text { the cutting edges } \\
{[\mu \mathrm{m}]}\end{array}$ & $\begin{array}{c}\text { Surface of kerf } \\
{\left[\mathrm{cm}^{2}\right]}\end{array}$ & $\begin{array}{c}\text { The average radius } \\
\text { of rounding of cut- } \\
\text { ting edges } \\
{[\mu \mathrm{m}]}\end{array}$ & $\begin{array}{c}\text { Standard deviation of } \\
\text { radius of rounding of } \\
\text { the cutting edges } \\
{[\mu \mathrm{m}]}\end{array}$ \\
\hline \multicolumn{3}{|c|}{ Pine. tense saw } & \multicolumn{3}{|c|}{ Pine. loose saw } \\
\hline 0 & 8.33 & 0.32 & 0 & 8.42 & 0.29 \\
\hline 5087 & 9.31 & 0.42 & 5065 & 9.86 & 0.47 \\
\hline 10174 & 10.27 & 0.56 & 10171 & 9.96 & 0.48 \\
\hline 15260 & 10.99 & 0.64 & 15156 & 11.86 & 0.81 \\
\hline 20347 & 11.99 & 0.79 & 20242 & 13.35 & 1.09 \\
\hline 25434 & 12.67 & 0.96 & 23307 & 14.67 & 1.18 \\
\hline 30521 & 13.17 & 1.09 & 30372 & 16.07 & 1.28 \\
\hline 35608 & 14.31 & 1.15 & 35438 & 17.21 & 1.49 \\
\hline \multicolumn{3}{|c|}{ Oak. tense saw } & \multicolumn{3}{|c|}{ Oak. loose saw } \\
\hline 0 & 8.62 & 0.37 & 0 & 9.06 & 0.34 \\
\hline 4273 & 9.33 & 0.77 & 4273 & 10.18 & 0.85 \\
\hline 8671 & 10.42 & 1.03 & 9045 & 11.39 & 1.46 \\
\hline 13069 & 12.05 & 1.32 & 13843 & 13.37 & 1.52 \\
\hline 17342 & 13.23 & 1.39 & 18367 & 15.77 & 1.56 \\
\hline 21614 & 15.22 & 1.68 & 22916 & 16.84 & 1.79 \\
\hline 26150 & 17.17 & 1.71 & 27829 & 18.87 & 2.15 \\
\hline 30686 & 18.06 & 1.72 & 32636 & 21.34 & 2.08 \\
\hline
\end{tabular}


of pine cutting with the use of the tensioned saw chain, after making 35 kerfs, SD of the average radius of rounding of the cutting edge was $1.15 \mu \mathrm{m}$, whereas in the case of the loose saw chain, SD value $(1.49 \mu \mathrm{m})$ was higher by 0.34 $\mu \mathrm{m}$. In the case of hardwood oak logs cutting with the use of the tensioned saw chain, SD value of the average radius of rounding of the cutting edge after 35 kerfs done was 1.72 $\mu \mathrm{m}$, and when the loose saw chain was used $-\mathrm{SD}=2.08 \mu \mathrm{m}$ $(0.36 \mu \mathrm{m}$ higher when compared to SD obtained when the tensioned saw chain was used).

The relationships between the radius of the blade rounding $r$ and the kerf area A can be presented by the following regression equations:

- pine wood, tensioned saw chain:

$r_{\text {Son }}=0.00016 A+8.4926, \mathrm{r}=0.94$

- pine wood, loose saw chain:

$r_{\text {Sol }}=0.00026 A+8.2985, \mathrm{r}=0.96$

- oak wood, tensioned saw chain:

$r_{D b l}=0.00031 A+8.0982, \mathrm{r}=0.93$

- oak wood, loose saw chain:

$$
r_{D b n}=0.00038 A+8.3532, \mathrm{r}=0.94
$$

The obtained values of the correlation coefficients indicate a strong dependence of the radius of the rounding of the cutting edge on the kerf area.

Figure 3 shows that when cutting both oak and pine wood, in the case of the tensioned saw chain, the cutting blades were blunting slower. Based on the regression equations obtained, it can be calculated that after achieving the kerf area of $30,000 \mathrm{~cm}^{2}$, the average rounding radius of the blades of the tensioned saw chain used for cutting pine wood increased by $4.8 \mu \mathrm{m}$ (from 8.5 to $13.3 \mu \mathrm{m}$ ), whereas in the case of the loose chain - by $7.8 \mu \mathrm{m}$ (from $8.3 \mu \mathrm{m}$ to $16.1 \mu \mathrm{m}$ ). The rounding radius of the blades in the loose chain increased by $63 \%$ more than that in the tensioned saw chain. In the case of oak wood cutting, the average radius of blade blunting increased by $9.3 \mu \mathrm{m}$ (from $8.1 \mu \mathrm{m}$ to 17.4 $\mu \mathrm{m})$, and when oak wood cutting was performed with the loose saw chain, the radius increased by $11.4 \mu \mathrm{m}$ (from 8.4 to $19.8 \mu \mathrm{m}$ ). For each species examined, faster blunting of the blades was found in the case of the loose saw chain. Both in the case of the tensioned and the loose saw chain, there was observed quicker blunting when oak wood was treated. This obviously results from the greater hardness and density of oak wood as compared to pine wood.

The effect of the kerf area on the cutting efficiency is presented in Figure 4.

The relationships between the area efficiency of cutting $W$ and the kerf area $A$ for different types of wood can be represented by the following regression equations:

- pine wood, tensioned saw chain: $W_{\text {Son }}=-0.0003 \mathrm{~A}+68.512, \mathrm{r}=0.5302$;

- pine wood, loose saw chain: $W_{\text {Sol }}=-0.0004 \mathrm{~A}+68.1010, \mathrm{r}=0.6878$;

- oak wood, loose saw chain: $W_{D b l}=-0.0003 \mathrm{~A}+56.514, \mathrm{r}=0.6535$;

- oak wood, tensioned saw chain: $W_{D b n}=-0.0005 \mathrm{~A}+46.139, \mathrm{r}=0.9477$.

Figure 4 shows that greater cutting efficiency was obtained in the case of pine wood. In this case, the difference between the effect achieved by the use of the tensioned saw chain and the use of the loose saw chain was irrelevant at the beginning of the work. However, in the process of blade blunting, the productivity obtained with the loose saw chain decreased. In the case of oak, from the beginning of the cutting process, significantly lower productivity was observed while cutting with the use of the loose saw chain. The strongest correlation between the obtained efficiency and the kerf area was found for oak wood cut with the tensioned saw chain.

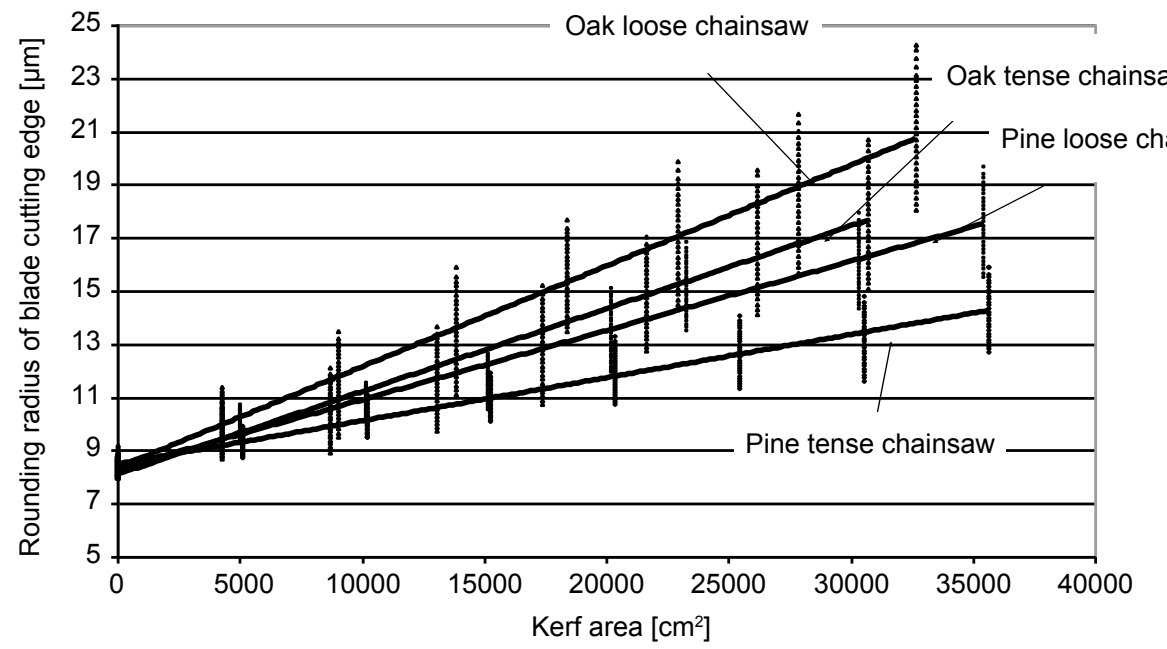

Figure 3. The dependence of the radius of the rounding of the cutting edge on the kerf surface for the tested wood species and different values of the initial tension pre-tension of the saw 


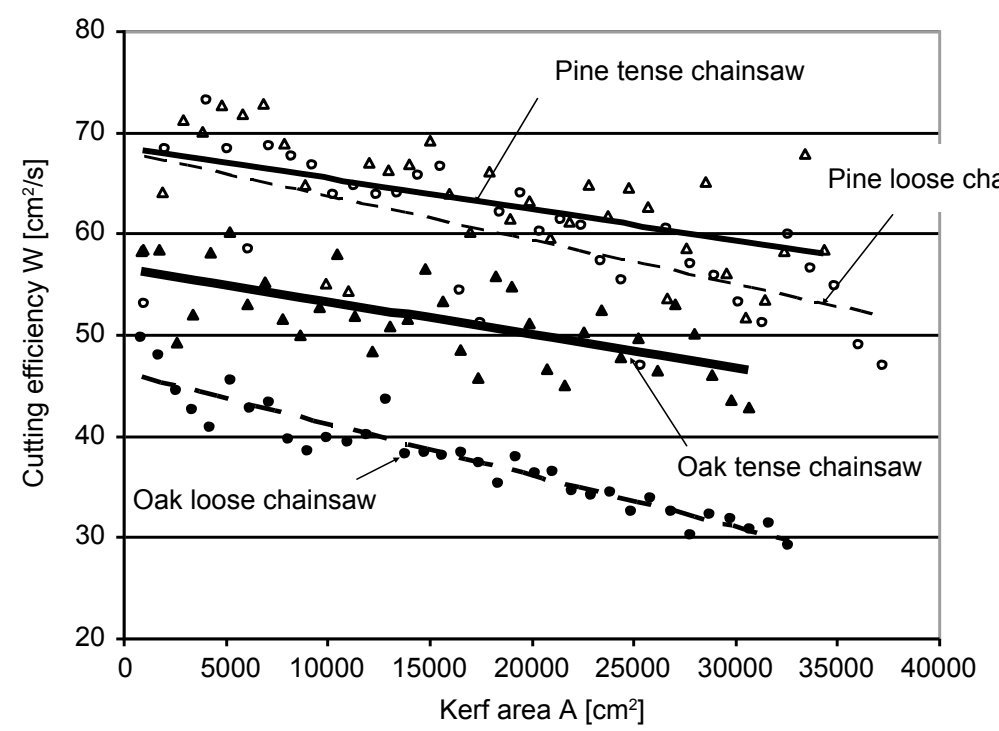

Figure 4. The dependence of the cutting efficiency on the kerf surface for different types of wood and the value of the initial tension of the saw

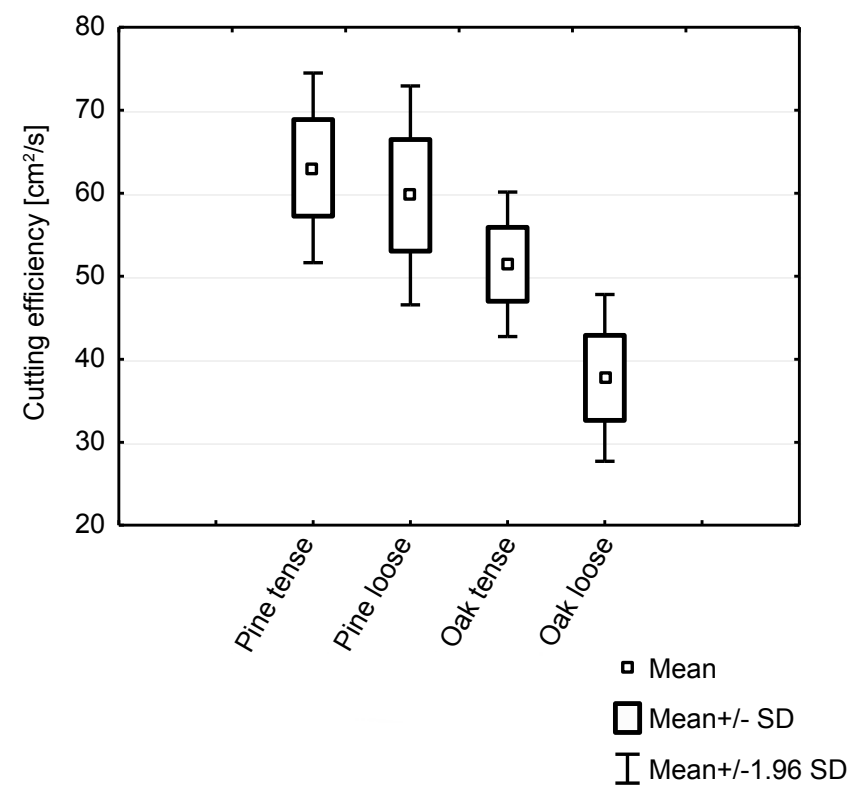

Figure 5 presents the average values of cutting efficiency for individual experiment variants during the whole period of saw chain blunting. Statistical analysis showed that the differences between all the average values obtained were significant. The average value of cutting efficiency obtained when the tensioned saw chain was used for cutting pine wood was $63.1 \mathrm{~cm}^{2} / \mathrm{s}$, whereas in the case of oak it was 51.4 $\mathrm{cm}^{2} / \mathrm{s}$. During cutting with the loose saw chain, the average cutting efficiency was $59.8 \mathrm{~cm}^{2} / \mathrm{s}$ for pine wood and 37.8 $\mathrm{cm}^{2} / \mathrm{s}$ for oak wood. In terms of the average cutting efficien- cy, with reference to pine wood, the difference between the tensioned and loose saw chains was $3.3 \mathrm{~cm}^{2} / \mathrm{s}$, whereas in the case of oak it was as much as $13.6 \mathrm{~cm}^{2} / \mathrm{s}$.

\section{Discussion}

Measurements performed in the present study did not take into account the factor that might significantly affect the end result of cutting, namely the feed force. Not inc- 
luding this parameter into the tests performed was due to the fact that under the conditions of the present study, the operator worked with the chainsaw, which was not placed on a special test stand, even though this was incorporated in other studies (Bieńkowski 1993; Górski 2001; Gendek 2005; Maciak 2013). For that reason, in the present study, it was not possible to achieve precise repeatability of the feed force and the position of the guide bar to the wood being processed. On the other hand, this allowed to bring the conditions of the experiment closer to the conditions of the work performed in the reality. Attaching the chainsaw to the bench changes chainsaw working conditions, including the course of the cutting process. According to the literature, the system 'operator-chainsaw' is a mass-flexibility-suppression system with many degrees of freedom and many natural vibration frequencies (Engel 2001). The frequency of the vibrations is in the range of natural frequency of human upper limbs. The value of this parameter depends on the course and continuity of the wood cutting process. The 'man-machine' system has a complex dynamic structure and constitutes the non-linear, stochastic and non-stationary system with parameters that change over time. Researchers agree that the natural frequency of the 'operator-machine' system depends on the operator's individual physical characteristics, position, fatigue and so on (Engel 2001; Cieślikowski 2007). Attaching the chainsaw to a laboratory bench would make the obtained results difficult to relate to the real work conditions.

The increase of the rounding radius of the cutting edge is faster in the case of the loose saw chain. With the increase of the kerf area, there is also an increase in the differences in the radius of the cutting edge of the individual cutting blade. The increase in the variability is also influenced by the reduction in the saw chain tension. In accordance with the chainsaw manual, the loose saw chain blunts faster when compared to the tensioned saw chain. Furthermore, in the case of the loose saw chain, there are observed greater differences in dulling of individual blades when compared with those in the tensioned saw chain. In the present study, the results of statistical tests showed that in all experiment variants, the kerf area significantly affected blade blunting. In all cases, the change in the radius of blade rounding as a function of the kerf area can be described by the equation of the straight line.

According to Gawlik (1988), the typical wear of the cutting blade, under dry friction conditions, can be graphically represented by the Lorenz curve. The course of cutting blade wearing consists in three characteristic periods: the preliminary blunting, normal blunting and end blunting. In the first period, there takes place smoothing of the friction surfaces. In the case of cutting, micro-irregularities of the blade surface are refined. The degree of wear depends largely on the level of blade surface roughness, and - to some extent, on blade geometry. The second period is characteri- zed by a constant wear intensity, depending on the working conditions (established at the end of the first period). This period lasts until these conditions change. In the third period, there occurs a relatively rapid increase in wear intensity, leading to the total loss of cutting ability by the blade. This happens as a result of wear parameters, which achieve certain values and a change in the established conditions of operation. On the basis of the character of the change in cutting edge radius, it can be stated that in all the examined cases, the saw chains were in the first and second period of cutting edge wear, characterized by constant wear intensity.

In all the investigated cases, pine cutting efficiency was greater than the efficiency obtained when cutting oak wood. This is due to the higher oak wood resistance to cutting when compared to pine wood (Orlicz 1988). Both for pine and oak, higher values of cutting efficiency were obtained with the use of the tensioned saw chain. The results obtained in the present study are confirmed by the findings of other authors, for example, Górski (1996) stated that the efficiency of cutting with the use of the loose saw chain was $50 \%$ lower when compared to that observed if the saw chain was properly tensioned. Maciak (2013) noted that the reason for this was the greater possibility of swinging the saw chain links in the kerf plane.

\section{Conclusions}

1. The initial tension of the saw chain has a significant influence on blade blunting rate and the cutting efficiency.

2. Cutting wood with the tensioned saw chain slows down blade blunting and allows for achieving greater cutting efficiency.

3. As compared to pine wood cutting, saw chain blades blunt quicker when cutting oak wood.

4. The increase of the radius of the rounding of the blade cutting edge depends on the tension of the saw chain and the type of wood cut. The smallest increase was observed when cutting pine wood with the tensioned saw chain, and the largest - when cutting oak wood with the use of the loose saw chain.

5. Chainsaw operators should be recommended to control the tension of the saw chain during work, and this will increase the efficiency of their labour as well as reduce the blade blunting rate.

\section{Conflict of interest}

The authors declare no conflict of interest.

\section{Acknowledgments and source of funding}

The study was carried out as a part of own research funding at the Department of Agricultural and Forestry Machines 
at the Warsaw University of Life Sciences (SGGW). The measurements were carried out at the Forest Experimental Station in Rogów and at the laboratory of the Department of Agricultural and Forest Machinery, the Faculty of Production Engineering at SGGW.

The authors thank the Reviewers for their valuable comments, which were used during the preparation of the manuscript.

\section{References}

Bieńkowski J. 1993. Wpływ stępienia ostrzy tnących na opory i wydajność skrawania piłą łańcuchową. Przegląd Techniki Rolniczej i Leśnej 12: 17-20.

Botwin J. Botwin M. 1979. Maszynoznawstwo Leśne. PWRiL, Warszawa. ISBN 83-09-00164-9.

Cieślikowski B. 2007. Procesy drganiowe w diagnostyce maszyn rolniczych. Polskie Towarzystwo Inżynierii Rolniczej, Kraków, 150 s. ISBN 83-917053-5-8.

Engel Z. 2001. Ochrona środowiska przed drganiami i hałasem. Wydawnictwo Naukowe PWN, Warszawa, 490 s. ISBN 83-01-13537-9.

Gawlik J. 1988. Prognozowanie stanu zużycia ostrzy narzędzi w procesie skrawania. Politechnika Krakowska, Monografia 66, Kraków, 197 s.

Gendek A. 2005. Wpływ parametrów sprzęgła na wydajność skrawania drewna pilarką spalinową. Praca doktorska. SGGW, Wydział Inżynierii Produkcji, Warszawa.

Gendek A. 2006. Wpływ parametrów silnika pilarki spalinowej na wydajność skrawania drewna. Technika Rolnicza, Ogrodnicza i Leśna 6: 23-25.

Gendek A. Oktabiński P. 2012. Engine power losses on resistance of chain saw motion over the guide. Annals of Warsaw University of Life Sciences - SGGW Agriculture (Agricultural and Forest Engineering) 60: 111-117.

Górski J. 1996. Analiza wpływu podstawowych czynników na wydajność i energochłonność procesu skrawania drewna piłą łańcuchową żłobikową. Praca doktorska. SGGW, Wydział Technologii Drewna, Warszawa.

Górski J. 2001. Proces cięcia drewna elektryczną pilarką łańcuchową. Wydawnictwo SGGW, Warszawa, 114 s. ISBN 83-7244-205-3.

Komorowski J. 1987. Wpływ geometrii ostrza żłobikowego piły łańcuchowej na skrawanie drewna sosnowego. Praca doktorska. Instytut Badawczy Leśnictwa, Warszawa.

Kusiak W., Moliński K., Walkowiak R. 2012. Model zużycia paliwa przy pozyskaniu drewna sosnowego. Sylwan 3: 218-224.

Maciak A. 2000. Forces acting on cutter of saw chain during wood cutting. Annals of Warsaw Agricultural University 36: 15-20.

Maciak A. 2001. Wpływ parametrów konstrukcyjnych ogniw tnących piły łańcuchowej żłobikowej na wydajność skrawania drewna. Praca doktorska. SGGW, Wydział Inżynierii Produkcji, Warszawa.
Maciak A. 2004. Influence of inclination angle of horizontal cutting edge of the chain saw link on cutting effects. Annals of Warsaw Agricultural University 45: 47-51.

Maciak A. 2011. Analiza rynku łańcuchowych pilarek spalinowych w Polsce. Technika Rolnicza, Ogrodnicza, Leśna 5: 2-4.

Maciak A. 2013. Wpływ czynników konstrukcyjnych i eksploatacyjnych na przebieg procesu i wydajność skrawania drewna pilarką spalinową. Rozprawy Naukowe i Monografie. Wydawnictwo SGGW, Warszawa, 122 s. ISBN 978-83-7583-421-5.

Maciak, A. Gendek A. 2007. Effect of cutting with the chain saws with two pairs of cutting links per section. Annals of Warsaw Agricultural University 50: 59-63.

Murawski P. 1995. Rynek pilarek spalinowych spalinowych Polsce - analiza podstawowych parametrów. Przegląd Techniki Rolniczej i Leśnej 12: 24-25.

Orlicz T. 1988. Obróbka drewna narzędziami tnącymi. Wydawnictwo SGGW, Warszawa, 504 s. ISBN 83-00-02116-7.

Statistica 10. 2011. Stat Soft. www. Statsoft.com

Stempski W., Grodecki J. 1998. Wpływ kąta zaostrzenia ogniw tnących na wydajność skrawania i trwałość pił łańcuchowych. Poznańskie Towarzystwo Przyjaciót Nauk. Prace Komisji Nauk Rolniczych i Leśnych 86: 73-82.

To T., Doi O., Yokoyama M. 1967. Cutting Behaviors of Saw Chain (Part 1). Kitami Institute of Technology Repository, Kitami Institute of Technology.

Trzeciak P. 2003. Wpływ napięcia i intensywności smarowania piły na wydajność skrawania drewna pilarką. Praca magisterska. SGGW, Wydział Leśny, Warszawa.

Więsik J. 1994. Model symulacyjny procesu skrawania drewna piłą łańcuchową. Przegląd Techniki Rolniczej i Leśnej 10: 17-19.

Więsik J. (red). 2002. Pilarki przenośne budowa i eksploatacja. Wydawnictwo Fundacja Rozwój SGGW, 236 s. ISBN 83-7274-041-0.

Więsik J. 2007. Obciążenie sprzęgła przenośnej pilarki spalinowej z piłą łańcuchową napędzaną silnikiem spalinowym. Przegląd Techniki Rolniczej, Ogrodniczej i Leśnej 2: 16-19.

Wójcik K. 2007. Analiza parametrów technicznych i eksploatacyjnych pilarek spalinowych oferowanych na rynku europejskim. Technika Rolnicza Ogrodnicza i Leśna 2: 5-8.

Wójcik K. 2014. Effect of kerf execution correctness during felling with internal combustion chain saw on direction of tree fall. Annals of Warsaw University of Life Sciences - SGGW Agriculture (Agricultural and Forest Engineering) 64: 89-96.

\section{Authors' contribution}

A.M. - research proposal, conception and methodology, literature review, measurements at the cutting stand, statistical analysis, discussion and conclusions, preparation of manuscript text; M.K. - literature review, measurements at the cutting stand, microscope measurements of the radius of rounding of the blade, compilation of data and preparation of results. 